\title{
A new depositional model for ice shelves, based upon sediment cores from the Ross Sea and the Mac. Robertson shelf, Antarctica
}

\author{
Eugene W. Domack, ${ }^{1}$ P.T. Harris ${ }^{2}$ \\ ${ }^{1}$ Department of Geology, Hamilton College, Clinton, NY 13323, U.S.A. \\ ${ }^{2}$ Antarctic CRC and Australian Geological Survey Organisation, Box 252-80, Hobart, Tasmania 7001, Australia
}

\begin{abstract}
We document the similarity of depositional facies occurring in gravity cores recovered from two disjunct regions of the Antarctic continental shelf: the Ross Sea and the Mac. Robertson shelf. The facies sequence model is represented in two cores, one collected during the 1995-1 cruise of the R/V Nathaniel B. Palmer (core NBP95 TC-18) and the other collected by the RSV Aurora Australis during cruise 149 in 1995 (core 149 39GC38). Both cores show a succession of facies indicative of ice-shelf retreat during the late-Pleistocene to Holocene transition. Distinct lithofacies range in thickness from a few tens of $\mathrm{cm}$ to $1 \mathrm{~m}$ and consist of (from bottom to top) a coarse, granulated sandy mud; laminated silt and clay; structureless silty clay; poorly sorted sandy siliceous mud; and siliceous mud and ooze. These facies represent the passage of distinct depositional regimes across the core sites, including sub-ice shelf beneath a basal debris zone; sub-ice shelf distal to a debris zone; calving-line transition; and open marine. This facies model represents an advance in our understanding of glacial marine stratigraphy for the Antarctic continental shelf and will provide the basis for more realistic palaeoglacial reconstructions.
\end{abstract}

\section{INTRODUGTION}

Despite many years of dedicated research on the nature of glacial marine sedimentation across the Antarctic continental shelf, depositional models have yet to be developed that can be applied to a wide range of settings in Antarctica. This is because many, but not all (Powell, 1994; Powell and others, 1996), of the processes associated with ice-shelf sedimentation have not been directly observed and must therefore be inferred from sediment cores or theoretical studies (Drewry and Cooper, 1981; Barrett and others, 1987; Alley and others, 1989; Kennedy and Anderson, 1989; Anderson and others, 1991; Domack and others, 1995). This approach is hampered by the incomplete recovery of past strati-

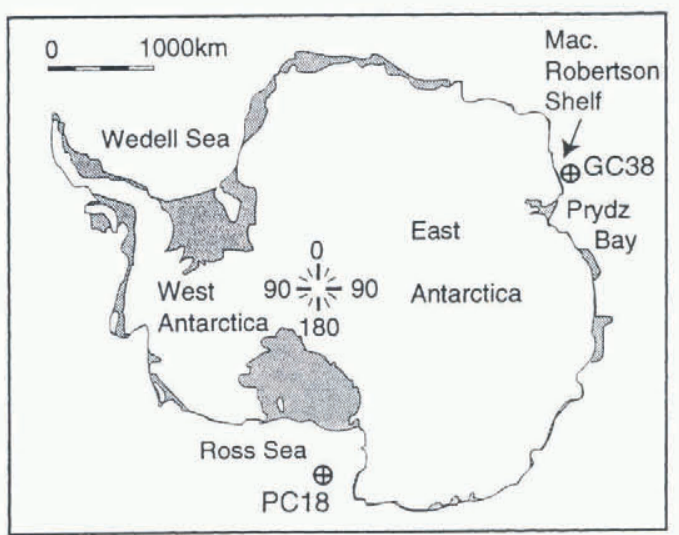

Fig. 1. Map of Antarctica, showing the locations of the core sites and geographic areas described in the text. The distribution of present floating ice shelves is indicated by the grey shading. graphic successions that can be most readily related to modern settings via Walther's law (e.g. Bennett and Glasser, 1996). Because of this lack of information, our ability to reconstruct the history of ice-sheet movements across the Antarctic continental shelf is limited to inferences derived from seismic stratigraphic studies that have advanced well beyond our ability to sample submarine sections directly.

This paper serves to relate specific depositional regimes thought to exist beneath and beyond ice shelves to stratigraphic lithofacies successions recovered in short gravity cores in two vastly different regimes, the inner Ross Sea continental shelf and the narrow Mac. Robertson shelf of East Antarctica (Fig. 1). Similarities between these two areas are related to the dominance of ice-shelf environments during deglaciation.

\section{STRATIGRAPHIC DESGRIPTION OF CORES}

\section{NBP95-1 TC 18}

Trigger (gravity) core NBP95-1 TC 18 (hereafter referred to as core TC 18) was recovered in the south central Ross Sea in a water depth of $819 \mathrm{~m}$. Within the $73 \mathrm{~cm}$ of sediment sampled in this core, we recognise five distinct lithofacies (Fig. 2), employing Folk and Ward's (1957) nomenclature, as modified by Moncrieff (1989):

(1) grey to brown, diatomaceous, clast-poor mud $(0-25 \mathrm{~cm})$;

(2) brown, diatomaceous, clast-rich mud $(25-29 \mathrm{~cm})$;

(3) structureless, bioturbated mud $(29-45 \mathrm{~cm})$;

(4) laminated to cross-bedded sandy mud and poorly sorted sand (45-62 cm; Fig. 3); and 
(5) a structureless, water-saturated, clast-rich sandy to intermediate diamicton, exhibiting a "granulated" texture (62-73 m).

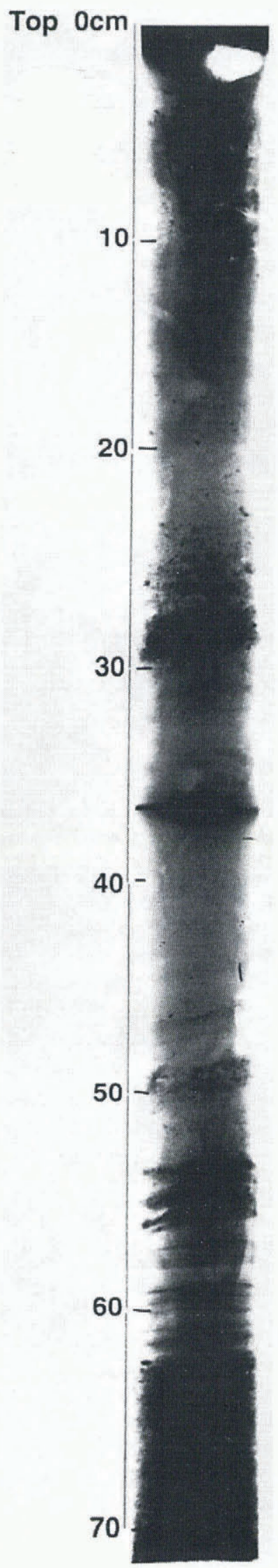

Fig. 2. X-ray photograph of core TC18, showing glacial marine muds with minor ice-rafted debris (IRD) from bottom to $62 \mathrm{~cm}$, laminated to bedded sand and mud from 62 to $29 \mathrm{~cm}$, abundant IRD gravel from 29 to $25 \mathrm{~cm}$, and bioturbated $S M O$ with minor IRD gravel from $25 \mathrm{~cm}$ to core top.
The "granulated" texture has previously been recognised in Antarctic marine sediments as a "brecciated" (O'Brien and Harris, 1996) or a "pelletised" texture (Domack and others, 1996). The granules have a grain-supported matrix of sandy mud, with cohesive granules of silty clay, and/or diamicton matrix. They are angular and very loosely compacted, lack observable grading but are size-sorted. Similar textures within cores from the Ross Sea were interpreted by Domack and others (1996) as a transitional-ice-shelf, rafted facies, deposited beneath basal debris zones and above till units. The internal texture of the granules is similar to that of "mud clots" described from basal debris zones of the Greenland and West Antarctic ice sheets (Gow and others, 1979; Gow and Meese, 1996).

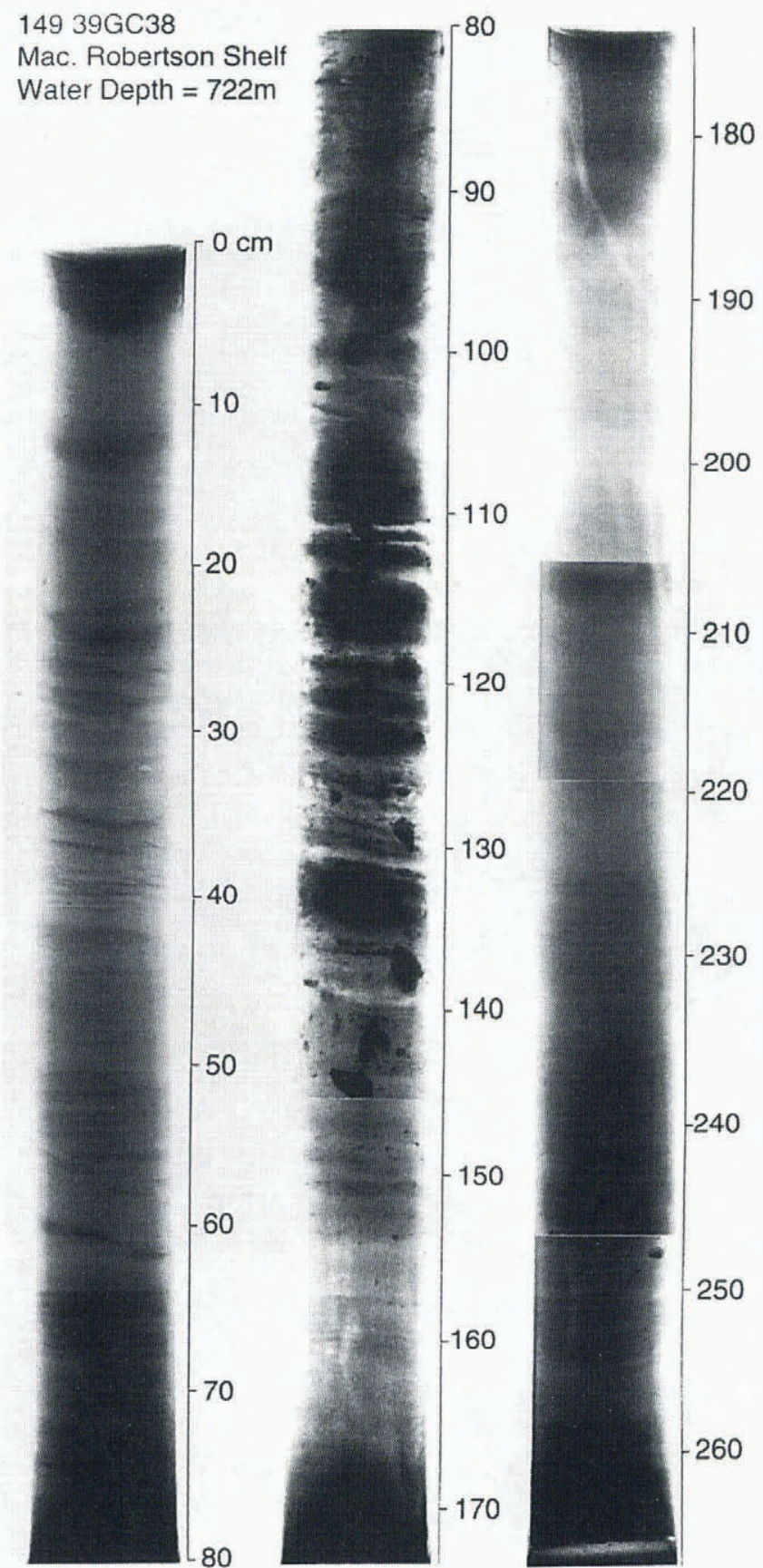

Fig. 3. X-ray photograph of core 38, showing glacial marine muds with minor IRD from bottom to $150 \mathrm{~cm}$, laminated to bedded sand and mud with abundant IRD gravel from 150 to $100 \mathrm{~cm}$, and ripple cross-bedded SMO from $100 \mathrm{~cm}$ to core top. 


\section{NBP95-1 PG 18}

This piston core was collected at the same time as core TC 18. Because of the force of impact with the piston core, much of the stratigraphy described above is missing from core PC 18. However, the following three units are recognised:

(1) disturbed brown diatomaceous mud $(0-10 \mathrm{~cm})$;

(2) structureless, granulated, water-saturated, clast-poor intermediate diamict $(10-18 \mathrm{~cm})$; and

(3) grey, structureless, cohesive clast-rich muddy diamicton $(18-55 \mathrm{~cm})$.

\section{39GC38}

Gravity core GC 38 was recovered from the Mac. Robertson shelf (Fig. 1) in $722 \mathrm{~m}$ water depth from a shelf valley system (Harris and others, 1996). It contained about $265 \mathrm{~cm}$ of sediment (Fig. 3) that can be divided into three different lithofacies:

(1) olive-green, stratified and cross-stratified siliciclastic and diatomaceous mud with intense bioturbation near the base $(0-110 \mathrm{~cm})$;

(2) stratified, diatomaceous, clast-poor muddy diamict (110$\sim 145 \mathrm{~cm}$ ); and

(3) massively bedded mud with rare clasts and common subvertical burrows ( $145-265 \mathrm{~cm})$.

\section{FACIES INTERPRETATION OF CORES}

Despite the widely separated locations of the two core sections described above, there are common lithofacies successions which we interpret as representing the retreat of an ice shelf. Ross Sea cores PC 18 and TC 18 are condensed sections and contain a complete succession of facies, while core 38, from the Mac. Robertson shelf, is an expanded section that sampled only three of the facies. We focus our interpretation around the inferred depositional processes beneath and in front of an ice shelf (Fig. 4).
The ice shelf and open marine system act together to produce a diversity of depositional rates and processes (Fig. 4) that we consider to be responsible for the stratigraphy observed in the cores described above. Most of the glacial sediment is supplied at the grounding line of the ice shelf. Landward of this zone, beneath the grounded ice sheet, structureless tills (diamictons) are deposited. This is represented by the basal unit in core PC 18, and in many other cores from the Ross Sea (Anderson and others, 1991; Domack and others, 1996).

At the grounding line, where the ice shelf lifts off the substrate, sea water intrudes beneath the ice shelf to form a thin layer of water that expands in a seaward direction. Debris in the base of the ice shelf is transported over this water column and as it melts it passively releases the entrained debris, of all particle sizes. Aggregates or granules of silty clay and sometimes sand can be found in the basal debris of polar ice sheets (Gow and Meese, 1996) and these are also released to the sea floor beneath the basal debris zone. The coarse, granulated facies found in cores PC 18 and TC 18 represent this grounding-line proximal zone. Powell and others (1996) observed that a similar zone extended about $1.5 \mathrm{~km}$ seawards of the grounding line at one location in the Ross Sea.

Currents, driven by tidal forcing or recirculation in the water column under the ice-shelf basal debris zone (Jenkins, 1991), induce lateral advection of fine grain-sizes so that mud and fine sand is winnowed, leaving a coarse, granulated diamict facies; currents are probably strongest proximal to the grounding line, due to the reduced cross-sectional area of the water column. The granulated diamict reaches its greatest thickness near the grounding line and thins and becomes finer-grained seawards (Fig. 4), as the basal debris zone loses its sediment load. Fine-grained sediments are transported by currents into a sub-ice-shelf zone that is distal to the grounding line. Seawards of the zone influenced by raining basal debris, coarse material is rare, although some well-sorted, very fine sand may occur. Facies characteristic of this zone of sorted glacial marine muds (Fig. 4) are represented by the laminated to massively bedded mud found in cores TC 18 and GC 38 (Figs 2 and 3). Cross-bedding, as seen in core TC-18,

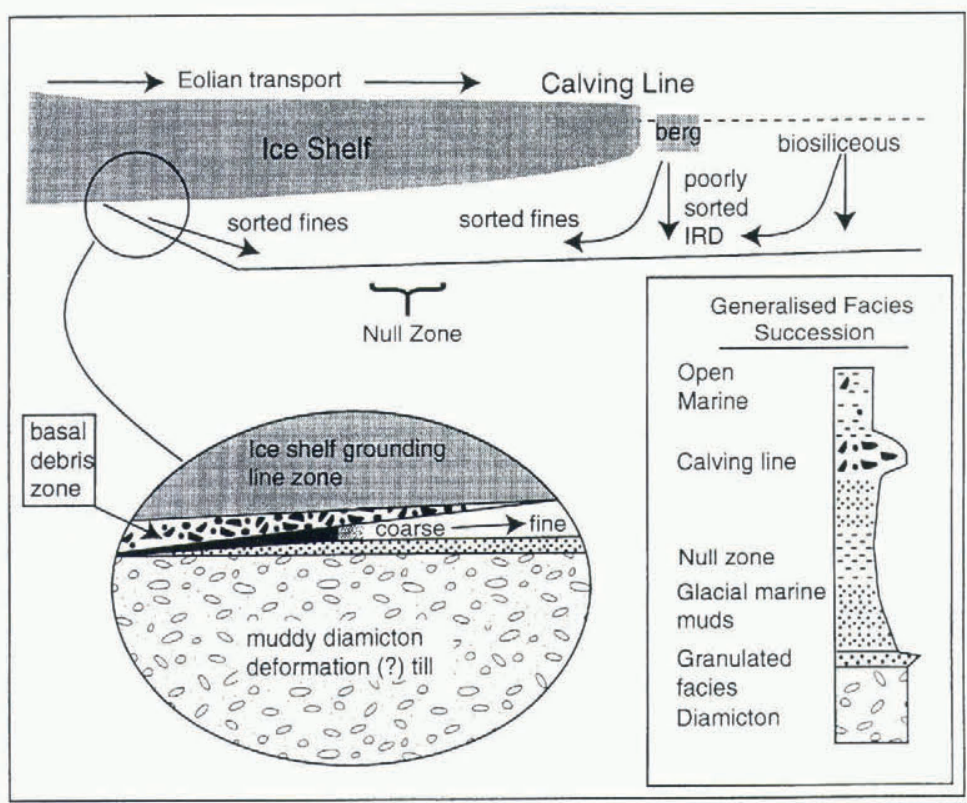

Fig. 4. Conceptual model showing facies deposited under a floating ice shelf, and generalised facies succession resulting from iceshelf retreat. 
may reflect the action of tidal currents within and near the grounding-line cavity (see also Nishimura and others, 1997).

With increasing distance seawards of the grounding line, and if the floating ice shelf is wide $(>5-10 \mathrm{~km})$, a "null zone" in sedimentation is eventually reached. At this null zone, only the finest particles are deposited and no ice-rafting occurs, presumably because most ice shelves are barren of debris at this distance seawards (Fig. 4). However, finegrained hemipelagic sediment is advected landwards under the ice shelf by recirculating currents, and this marine influence increases in a seawards direction (Fig. 4). The advected marine sediment includes diatoms and other phytoplankton, together with fine-grained, iceberg-rafted debris released in the open marine setting. The null zone is represented by well-sorted, fine-grained, massively bedded sediments which occur in core TC 18 at about $35-40 \mathrm{~cm}$ and in core GC 38 at about $170-220 \mathrm{~cm}$ (Figs 2 and 3).

At the calving line, a concentration of coarse, icebergrafted debris is deposited (Fig. 4). This is a widespread facies believed to be related to the concentration of icebergs by winds at the calving line and/or aeolian transport of material from inland across the ice shelf, with consequent deposition in the sea. Iceberg residence time is clearly greater at an ice-shelf barrier under favourable winds than it is in the open marine setting, and so a high concentration of debris is deposited (Domack and Ishman, 1993; Domack and others, 1995). Often this debris is of a provenance distinct from the basal debris. In the Ross Sea, iceberg detritus is dominated by volcaniclastic material derived from Cenozoic volcanic rock, whereas the basal debris is Mesozoic to Palaeozoic crystalline rock (Anderson and others, 1991; Domack and others, 1996). This facies is found in core TC 18 at $25-30 \mathrm{~cm}$ and in core GC 38 at $110-145 \mathrm{~cm}$ (Figs 2 and 3).

Seawards of the ice shelf, the open marine setting dominates and siliceous mud and ooze (SMO), with rare iceberg-rafted detritus, accumulates. Some of this SMO is redeposited by dilute gravity flows or density currents (note ripple cross-bedding at $0-80 \mathrm{~cm}$ in GC 38; Fig. 3), although it mainly accumulates as a massively bedded pelagic and hemipelagic unit (TC 18). The SMO is variable in its thickness across the shelf, being thickest $(>5 \mathrm{~m})$ in deep troughs and thin $(<1 \mathrm{~m})$ over banks. Its age is Holocene, as demonstrated by a number of studies (Domack and others, 1991; Pudsey and others, 1994; Harris and others, 1996).

\section{SUMMARY AND GONCLUSIONS}

The importance of the facies model presented herein is that it can be tested against an increasing data base of shelf sediment cores being collected by various national programmes. In particular, it allows for the recognition of a distinct facies succession (Fig. 4) related to ice-shelf retreat that can be used to assess the dynamics of ice-sheet and ice-shelf systems when coupled with age-dating techniques (Anderson and Molnia, 1989; Kennedy and Anderson, 1989; Anderson and others, 1991; Domack and others, 1995; Harris and others, 1996). It is based upon a sound observational data base and theoretical considerations of the depositional environments that are to be expected in an ice-sheet/shelf system.

\section{ACKNOWLEDGEMENTS}

The work was financially supported by the U.S. National
Science Foundation grant No. OPP91-18462, by the Cooperative Research Centre for the Antarctic and Southern Ocean Environment, University of Tasmania, and by the Australian Geological Survey Organisation. Thanks to R. Powell and J. Anderson for critical comments on an earlier version of this paper. P.T.H. publishes with the permission of the Executive Director, Australian Geological Survey Organisation.

\section{REFERENCES}

Alley, R.B., D. D. Blankenship, S. T. Rooney and C. R. Bentley. 1989. Sedimentation beneath ice shelves - the view from Ice Stream B. Mar. Geol., $85(2 / 4), 101-120$.

Anderson, J. B. and B. F. Molnia. 1989. Glacial-marine sedimentation. Washington, DC, American Geophysical Union. (Short Course in Geology 9.)

Anderson, J. B., D. S. Kennedy, M. J. Smith and E.W. Domack. 1991. Sedimentary facies associated with Antarctica's floating ice masses. In Anderson, J. B. and G. M. Ashley, eds. Glacial marine sedimentation; paleoclimatic significance. Boulder, CO, Geological Society of America, 1-25. (GSA Special Paper 261.)

Barrett, P. J., D. P. Elston, D. M. Harwood, B. C. McKelvey and P. N. Webb. 1987. Mid-Cenozoic record of glaciation and sea level change on the margin of the Victoria Land basin, Antarctica. Geology, 15(7), 634- 637.

Bennett, M. R. and N. F. Glasser. 1996. Glacial geology: ice sheets and landforms. Chichester, etc., John Wiley and Sons.

Domack, E.W. and S. Ishman. 1993. Oceanographic and physiographic controls on modern sedimentation within Antarctic fjords. Geol. Soc. Am. Bull., 105(9), 1175-1189.

Domack, E.W., A.J.T. Jull and S. Nakao. 1991. Advance of East Antarctic outlet glaciers during the hypsithermal: implications for the volume state of the Antarctic ice sheet under global warming. Geology, 19(11), 1059-1062.

Domack, E. W., S. E. Ishman, A. B. Stein, C. E. McClellen and A. J. T. Jull. 1995. Late Holocene advance of the Müller Ice Shelf, Antarctic Peninsula: sedimentological, geochemical and palaeontological evidence. Antarct. Sci., 7(2), 159-170.

Domack, E.W., S. Shipp and E. A. Jacobsen. 1996. Finally a realistic model for ice shelf sedimentation: new cores collected from the Ross Sea, Antarctica. Geol. Soc. Am. Abstr. Programs, 28, A506.

Drewry, D. J. and A. P. R. Cooper. 1981. Processes and model of Antarctic glaciomarine sedimentation. Ann. Glaciol., 2, 117-122.

Folk, R. L. and W. C. Ward. 1957. Brazos River bar: a study in the significance of grain size parameters. F. Sediment. Petrol., 27(1), 3-26.

Gow, A. J. and D. A. Meese. 1996. Nature of basal debris in the GISP2 and Byrd ice cores and its relevance to bed processes. Ann. Glaciol., 22, 134-140.

Gow, A. J., S. Epstein and W. Sheehy. 1979. On the origin of stratified debris in ice cores from the bottom of the Antarctic ice sheet. J. Glaciol., 23 (89), $185-192$.

Harris, P.T., P. E. O'Brien, P. Sedwick and E. M. Truswell. 1996. Late Quaternary history of sedimentation on the Mac. Robertson shelf, East Antarctica: problems with ${ }^{14} \mathrm{C}$ dating of marine sediment cores. Pap. Proc. R. Soc. Tasmania, $130(2), 47-53$.

Jenkins, A. 1991. A one-dimensional model of ice shelf-ocean interaction. 7 . Geophys. Res., 96 (C11), 20,671-20,677.

Kennedy, D. S. and J. B. Anderson. 1989. Quaternary glacial history of Marguerite Bay, Antarctic Peninsula. Quat. Res., 31, 375-387.

Moncrieff, A. C. M. 1989. Classification of poorly sorted sedimentary rocks. Sediment. Geol., 65(1-2), 191-194.

Nishimura, A., T. Nakasone, C. Hiramatsu and M. Tanahashi. 1998. Late Quaternary palaeoenvironment of the Ross Sea continental shelf, Antarctica. Ann. Glaciol., 27 (see paper in this volume).

O'Brien, P. E. and P.T. Harris. 1996. Patterns of glacial erosion and deposition in Prydz Bay and the past behaviour of the Lambert Glacier. Pap. Proc. R. Soc. Tasmania, 130 (2), 79-85.

Powell, R. D. 1994. Processes and facies of glacier grounding-line systems with inferences on lithofacies architecture and seismic stratigraphy. Terra Antartica, 1(2), Special Issue, 433-434.

Powell, R. D., M. Dawber, J. N. McInnes and A. R. Pyne. 1996. Observations of the grounding-line area at a floating glacier terminus. Ann. Glaciol., 22, 217-223.

Pudsey, C. J., P. F. Barker and R. D. Larter. 1994. Ice sheet retreat from the Antarctic Peninsula shelf. Continental Shelf Res., 14(15), 1647-1675. 